\title{
Hyperkalemia and acute kidney failure associated with preoperative uterine artery embolization for a large uterine fibroid: a case report
}

\author{
Keiko Tanaka, Toshimitsu Koizumi ${ }^{*}$ Takeru Higa ${ }^{*}$ and Noriaki Imai
}

\begin{abstract}
Background: Preoperative uterine artery embolization has been shown to help reduce blood loss, with few complications. Most reports indicated that uterine artery embolization is safe for uterine fibrosis; the occurrence of hyperkalemia and acute kidney failure as complications of preoperative uterine artery embolization has not been reported previously. Here we report the occurrence of hyperkalemia and acute kidney failure after preoperative uterine artery embolization for a large uterine fibroid. To the best of our knowledge, this is the first report on the occurrence of hyperkalemia and acute kidney failure after preoperative uterine artery embolization.
\end{abstract}

Case presentation: A 48-year-old Japanese woman presented to our hospital complaining of compression in her abdomen and an abdominal mass. Magnetic resonance imaging showed a large uterine fibroid measuring 37. $5 \times 27 \times 13.5 \mathrm{~cm}$. Therefore, we planned preoperative uterine artery embolization to help reduce blood loss. However, hyperkalemia and acute kidney failure occurred owing to the development of necrotic tissue after uterine artery embolization; therefore, emergency total abdominal hysterectomy and bilateral salpingo-oophorectomy were performed. She experienced $105 \mathrm{~g}$ of blood loss intraoperatively. The weight of her uterus was $10.8 \mathrm{~kg}$ and the volume was $9964 \mathrm{~cm}^{3}$, with extensive necrotic tissue. Her hyperkalemia and kidney failure resolved after the surgery.

Conclusions: We reported the occurrence of serious complications, including hyperkalemia and acute kidney failure, after preoperative uterine artery embolization for a large uterine fibroid.

Keywords: Uterine artery embolization, Uterine fibrosis, Complications, Hyperkalemia, Acute kidney failure

\section{Background}

Uterine artery embolization (UAE) for the treatment of uterine fibroids was first reported in 1995 [1], and since then, many reports [2-15] have described the risks and benefits of UAE. Some reports [12-15] stated that preoperative UAE can help reduce bleeding, and most reports indicated that UAE is safe for uterine fibroid. David et al. [15] reported that patients undergoing a hysterectomy with a uterine weight of more than $1000 \mathrm{~g}$ have a significantly higher risk of perioperative complications and are at greater risk of requiring a blood transfusion. David and Kröncke [15] also reported that only

\footnotetext{
*Correspondence: koijumit@yahoo.co.jp; ryukyu.takeru@gmail.com; nimai0819@gmail.com

Hachinohe City Hospital, Hachinohe City, Japan
}

two of the three patients with myomata weighing more than $1100 \mathrm{~g}$ were able to avoid blood transfusion, because of preoperative UAE. The occurrence of hyperkalemia and acute kidney failure as complications of preoperative UAE has not been reported previously. Here we report the occurrence of hyperkalemia and acute kidney failure after preoperative UAE for a large uterine fibroid. To our knowledge, this is the first report on the occurrence of hyperkalemia and acute kidney failure after preoperative UAE.

\section{Case presentation}

A 48-year-old Japanese woman with a medical history of multiple sclerosis presented to our hospital complaining of compression in her abdomen and an abdominal mass. 
Magnetic resonance imaging revealed a uterine fibroid measuring $37.5 \times 27 \times 13.5 \mathrm{~cm}$ along with some small fibroids (Figs. 1 and 2). We planned total abdominal hysterectomy and bilateral salpingo-oophorectomy 3 days after UAE.

Embolization of her bilateral uterine arteries and selective embolization of her left bladder artery were performed using a gelatin sponge (Figs. 3 and 4), because her left bladder artery (Fig. 3, arrow) supplied the uterine fibroid. However, 12 hours after embolization, she experienced cold sweats and vomiting, and 15 hours after embolization, hyperkalemia was noted on venous blood analysis and acute kidney failure was identified (Table 1). Arterial blood gas analysis showed compensated metabolic acidosis: $\mathrm{pH}, 7.368$; partial pressure of carbon dioxide $\left(\mathrm{pCO}_{2}\right), 27.3 \mathrm{mmHg}$; base excess, -8.2; and bicarbonate $\left(\mathrm{HCO}_{3}\right), 15.4 \mathrm{mmol} / \mathrm{L}$. Glucose-insulin therapy was administered; however, it was not successful in resolving her condition. She then received continuous hemodiafiltration in our intensive care unit; however, her hyperkalemia and kidney failure did not improve. Therefore, she underwent emergency surgery. Total abdominal hysterectomy and bilateral salpingooophorectomy were performed, and her intraoperative blood loss was $105 \mathrm{~g}$ (Figs. 5, 6, and 7). The weight of her uterus was $10.8 \mathrm{~kg}$ and the volume was $9964 \mathrm{~cm}^{3}$. The volume was calculated using the formula: volume $=$ length $(\mathrm{cm}) \times$ width $(\mathrm{cm}) \times$ diameter $(\mathrm{cm}) \times 0.5233($ Fig. 8). She underwent autotransfusion $(800 \mathrm{~mL})$ and received 1200 $\mathrm{mL}$ of packed red blood cells. Her uterus had necrotic tissue, and the pathological finding was uterine fibrosis with

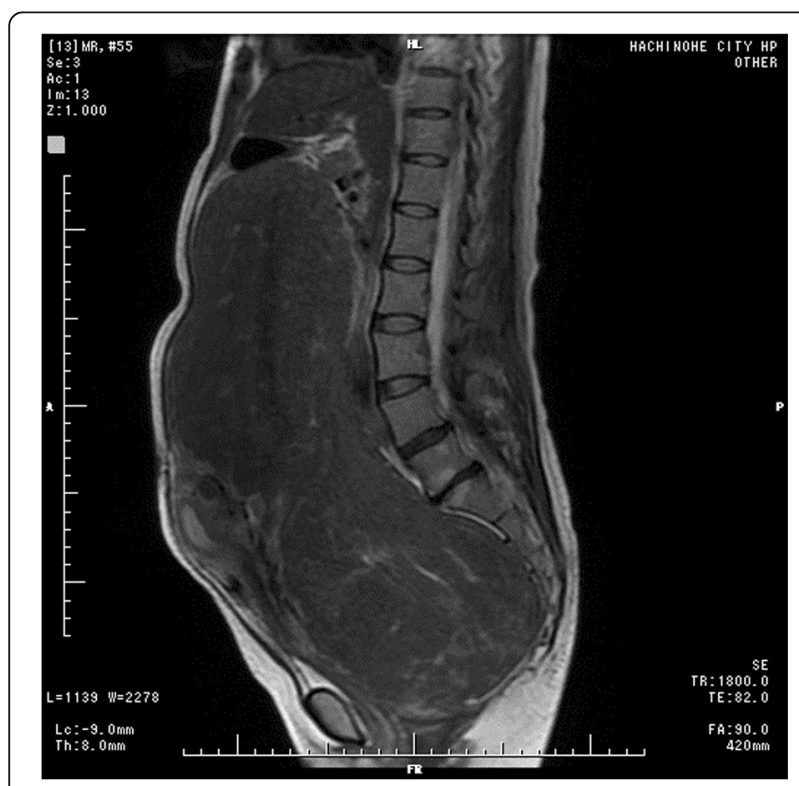

Fig. 1 A sagittal T2-weighted magnetic resonance image of the uterus

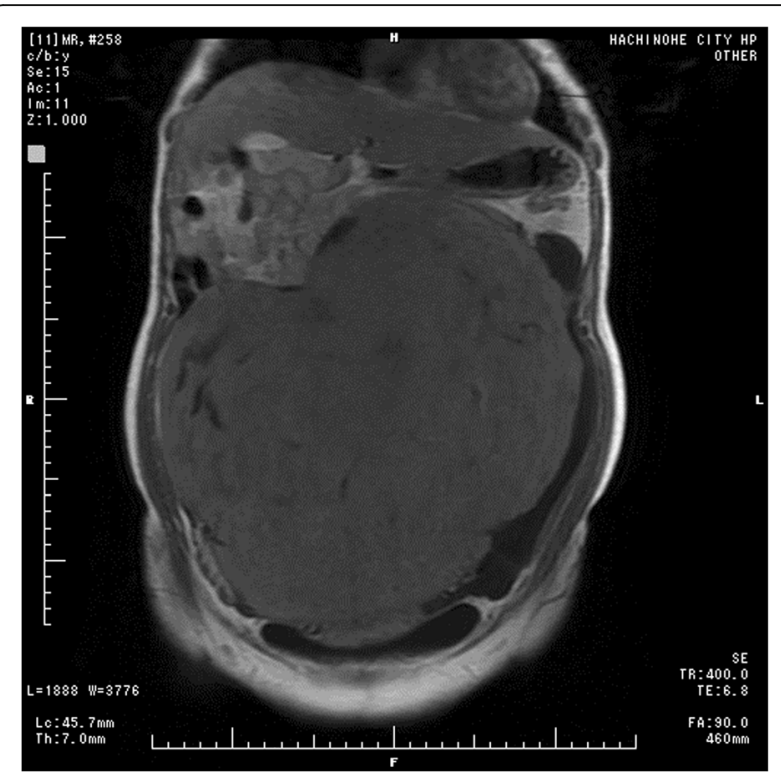

Fig. 2 A coronal T2-weighted magnetic resonance image of the uterus

necrosis (Figs. 9 and 10). Following surgery, her hyperkalemia and kidney failure resolved.

\section{Discussion}

Previous reports [2-15] mentioned that most women who underwent UAE for uterine fibroids were satisfied with the clinical outcome and had few complications.

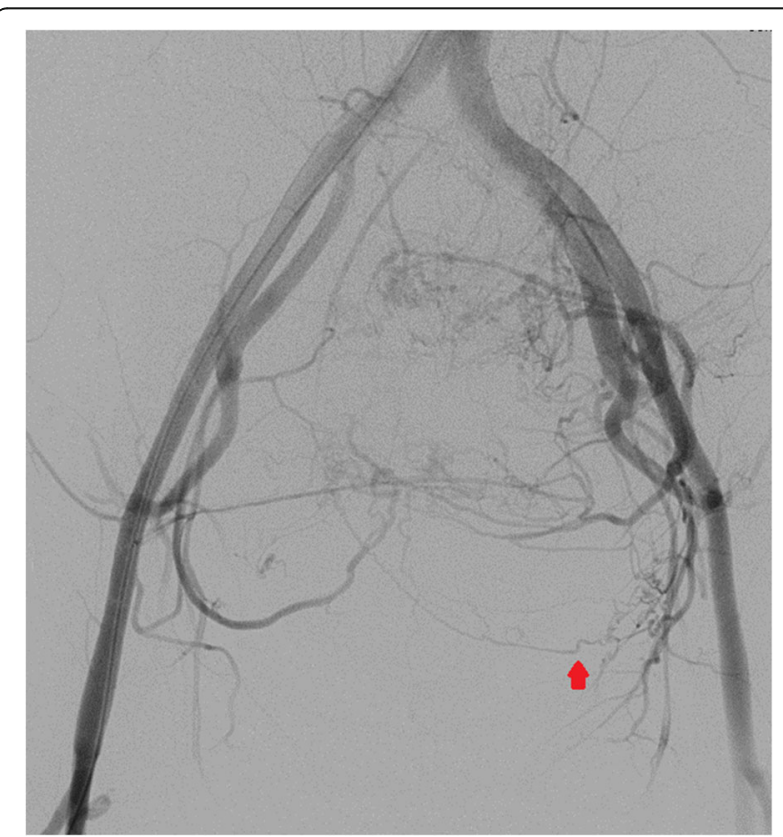

Fig. 3 An angiography image obtained before uterine artery embolization. The left bladder artery (arrow) supplied a uterine fibroid 


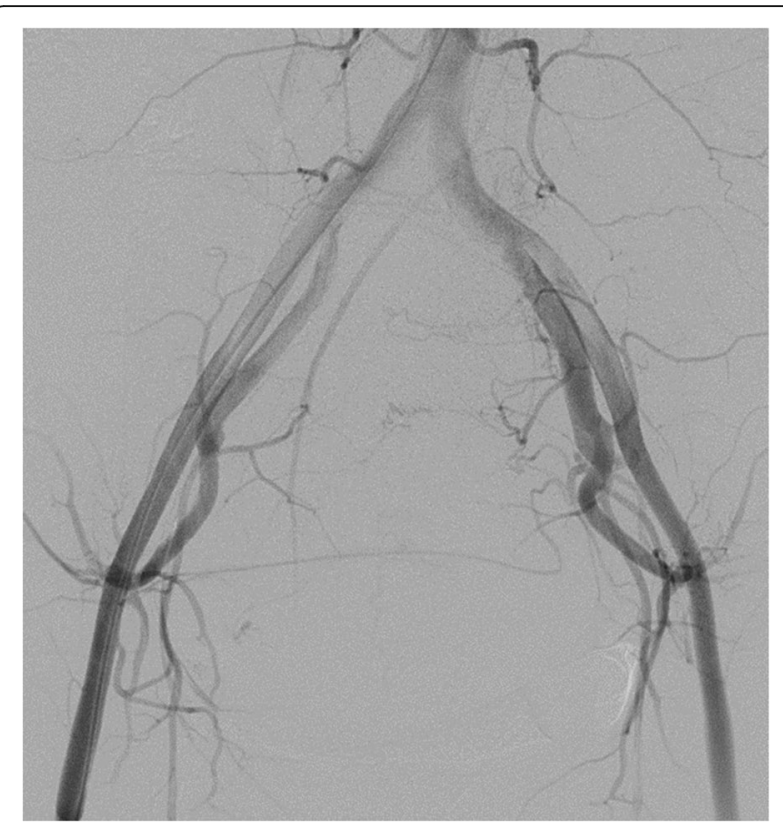

Fig. 4 An angiography image obtained after uterine artery embolization

Table 1 Results of venous blood analysis 15 hours after uterine artery embolization

\begin{tabular}{ll}
\hline Test & Value \\
\hline White blood cell count $(\mu \mathrm{L})$ & 24800 \\
Red blood cell count $\left(\times 10^{4} / \mu \mathrm{L}\right)$ & 454 \\
Hemoglobin $(\mathrm{g} / \mathrm{dL})$ & 13.3 \\
Hematocrit $(\%)$ & 39.3 \\
Platelet count $\left(\times 10^{4} / \mathrm{mL}\right)$ & 32.5 \\
Total protein $(\mathrm{g} / \mathrm{dL})$ & 9.4 \\
Albumin $(\mathrm{g} / \mathrm{dL})$ & 4.7 \\
Potassium $(\mathrm{mEq} / \mathrm{L})$ & 8.0 \\
Sodium (mEq/L) & 134 \\
Chloride $(\mathrm{mEq} / \mathrm{L})$ & 96 \\
Blood urea nitrogen $(\mathrm{mg} / \mathrm{dL})$ & 28 \\
Creatinine $(\mathrm{mg} / \mathrm{dL})$ & 2.02 \\
Creatine kinase $(\mathrm{IU} / \mathrm{L})$ & 301 \\
Lactate dehydrogenase $(\mathrm{IU} / \mathrm{L})$ & 363 \\
Aspartate transaminase $(\mathrm{IU} / \mathrm{L})$ & 33 \\
Alanine transaminase $(\mathrm{IU} / \mathrm{L})$ & 17 \\
Alkaline phosphatase $(\mathrm{IU} / \mathrm{L})$ & 262 \\
C-reactive protein $(\mathrm{mg} / \mathrm{dL})$ & 1.49 \\
Activated partial thromboplastin time (s) & 25.6 \\
Prothrombin time international normalized ratio & 1.04 \\
Fibrinogen (mg/dL) & 452 \\
\hline
\end{tabular}

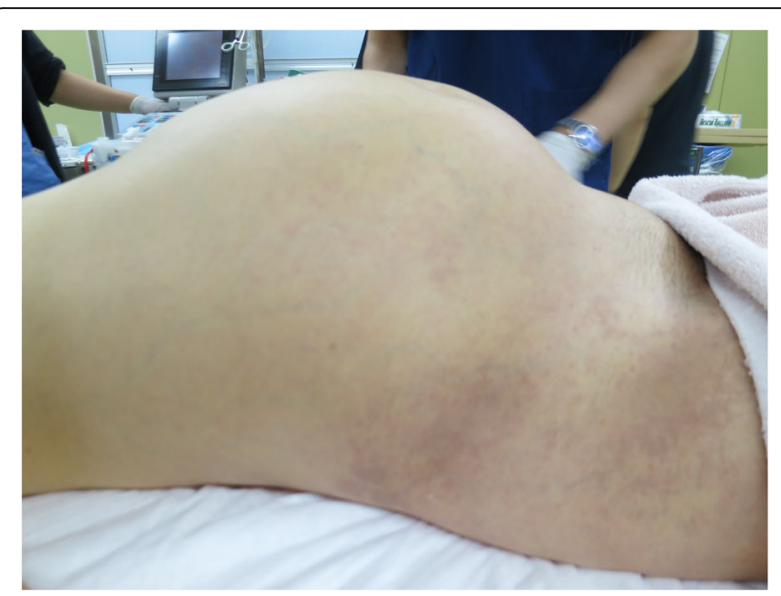

Fig. 5 An image of the patient's abdomen before surgery

Although complications have been reported after UAE, hyperkalemia and kidney failure have not been reported previously.

The complication rate associated with UAE has been reported to be very low, and most complications have been found to be transient [2]. The most serious complication associated with UAE is endometritis/uterine infection, with a reported incidence of approximately $2 \%$ [2-4]; however, the associated morbidity rate was found to be very low [2]. Complications following UAE can be classified into immediate (peri-procedure), early (within 30 days), and late (beyond 30 days) complications [5]. Most immediate complications are local complications,

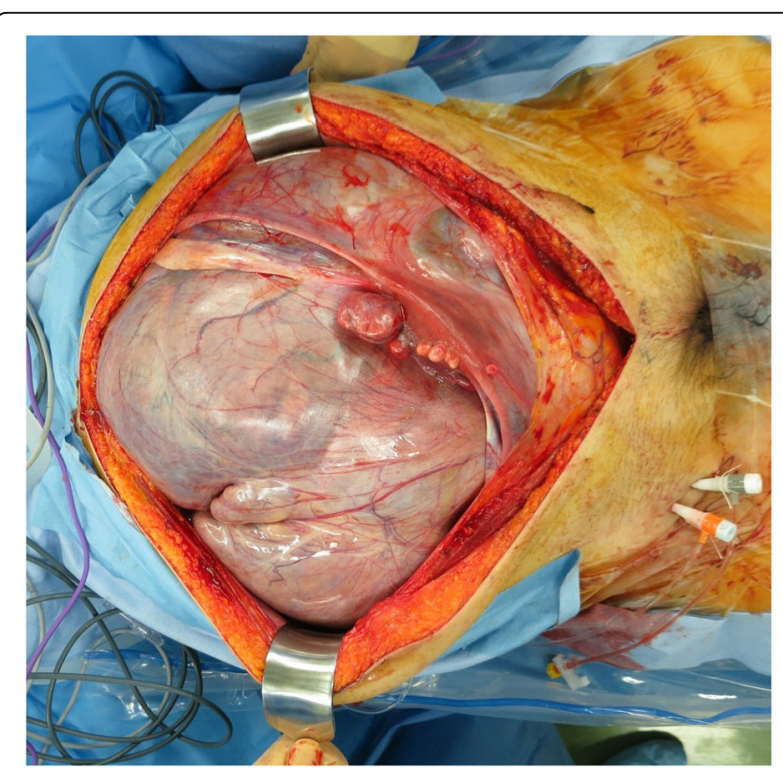

Fig. 6 An image of the abdomen obtained during the surgery. The uterus occupies a large part of the intraperitoneal space 


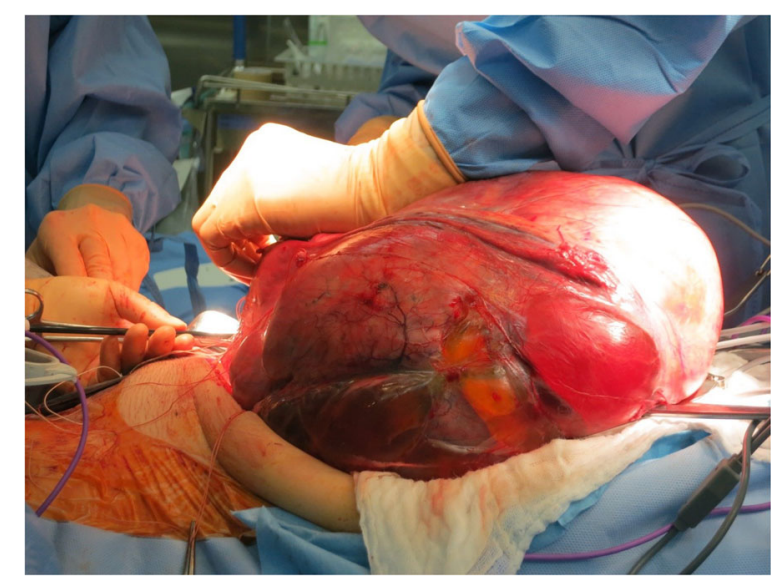

Fig. 7 An image of the uterus during the surgery

such as hematoma, arterial thrombosis, dissection, and pseudoaneurysm, and other complications include spasm and non-target embolization [5]. Non-target embolization is relatively rare, and it does not occur if a good technique is used [5]. Most early complications are associated with post-embolization syndrome and include pain, nausea, fever, and malaise, and other complications are rare [5]. Most complications of UAE have been shown to occur more than 30 days after the procedure [5]. Late complications include vaginal discharge, fibroid expulsion and impaction, infection, amenorrhea, and sexual dysfunction [5]. The rate of hysterectomy subsequent to UAE ranges from 0.25 to $1.6 \%$ [2-4]. Uterine necrosis is a rare complication after UAE, and it necessitates hysterectomy and treatment with antibiotics to prevent bacteremia, sepsis, and death $[2,6]$. In our case, we believe that the uterine fibroids became necrotic following UAE and the necrotic tissue caused hyperkalemia and acute kidney

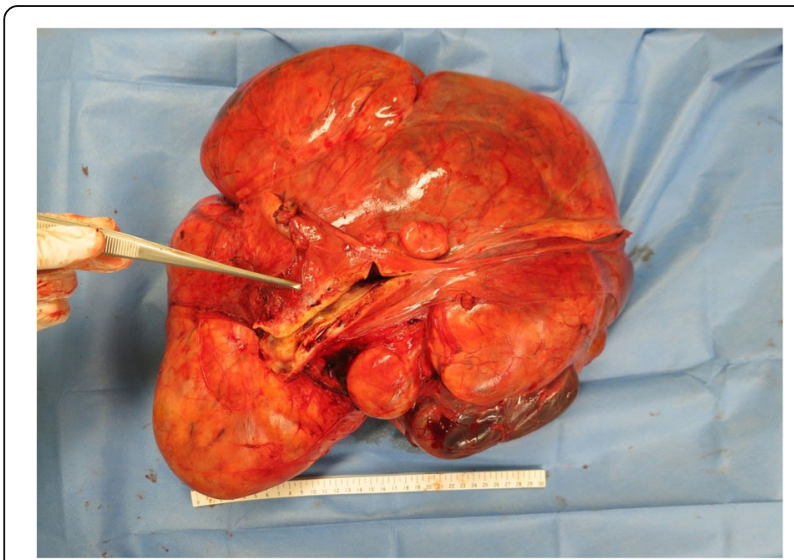

Fig. 8 An image of the excised specimen

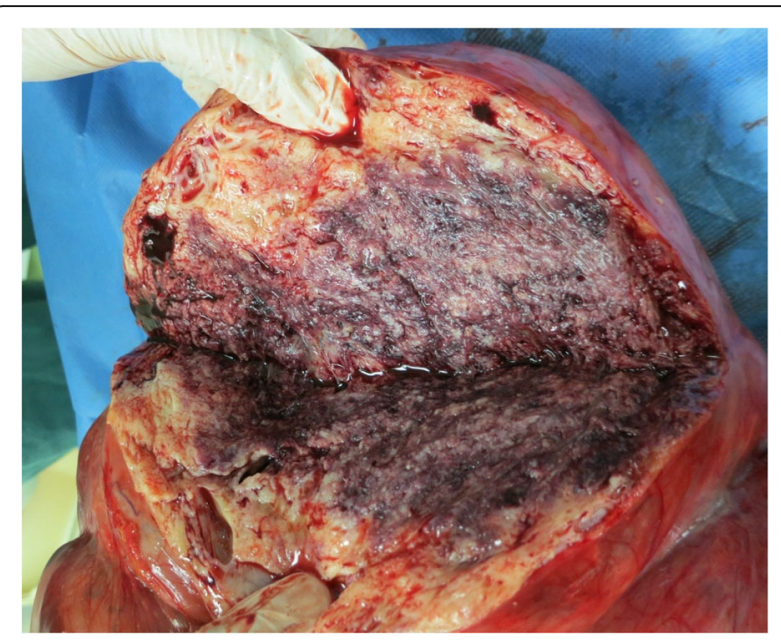

Fig. 9 An image showing necrosis within the excised specimen

failure. Some reports have mentioned that patients with a septic uterus required urgent surgery 7 or more days after the initial procedure $[2,6]$. However, in our case, necrotic tissue caused serious complications and necessitated surgical intervention within 48 hours. In addition, our patient needed a blood transfusion in spite of the small intraoperative blood loss; we think a blood transfusion was needed because after UAE the necrotic uterine fibroids lost blood.

Previous reports found that the size of the uterine fibroid was not associated with complications after UAE [7-10]. In one report, complications were found to be associated with a large uterus size $(500 \mathrm{~mL})$, large dominant tumor volume $\left(100 \mathrm{~cm}^{3}\right)$, and high postintervention creatine kinase level (170 U/L) [11]. Among previous reports, the largest fibroid was approximately $4000 \mathrm{~cm}^{3}$ [7-10], while the uterus in the present case

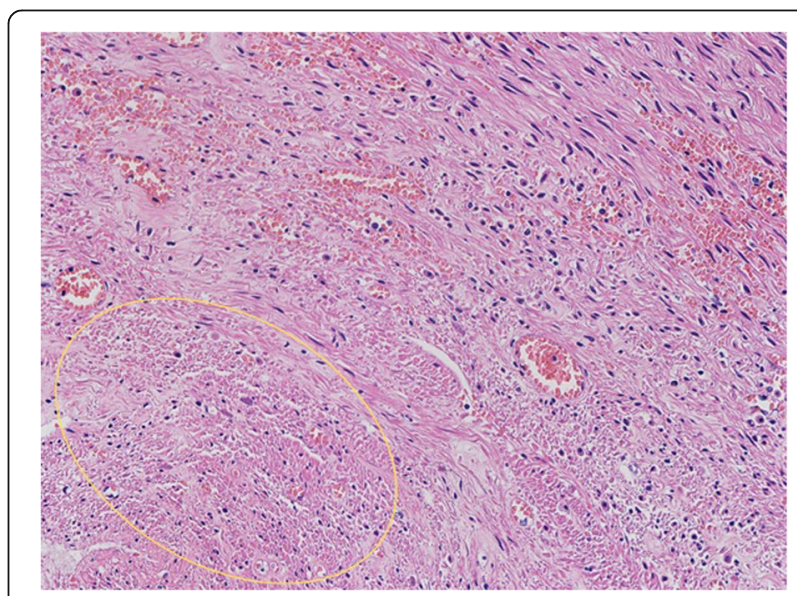

Fig. 10 A histological image showing necrotic cells (yellow circle). Hematoxylin and eosin stain, $\times 400$ 
was $9964 \mathrm{~cm}^{3}$; therefore, it was not possible to generalize the previous findings to the present case. In our case, fibroid volume was the most important risk factor for serious complications.

It has been reported that surgical intervention should be performed within 48 hours after preoperative UAE [12-15]. Therefore, for the prevention of serious complications, such as those in the present case, we suggest that surgical intervention should be performed immediately after preoperative UAE.

\section{Conclusions}

We reported the occurrence of serious complications, including hyperkalemia and acute kidney failure, after preoperative UAE for a large uterine fibroid. Preoperative UAE is effective for preventing blood loss. The findings of the present case indicate that UAE performed for a large uterine fibroid can cause hyperkalemia and acute kidney failure.

\section{Acknowledgements}

We would like to thank the consultants of the Division of Gynaecology, the Department of Emergency Medicine, and the Department of Pathological Medicine, Hachinohe City Hospital.

\section{Funding}

There is no source of funding for the preparation of this manuscript.

Availability of data and materials

Not applicable.

\section{Authors' contributions}

$\mathrm{KT}$, TK and TH carried out surgical intervention. $\mathrm{KT}, \mathrm{TK}, \mathrm{TH}$, and $\mathrm{NI}$ contributed to the discussion of this case. All authors read and approved the final manuscript.

\section{Competing interests}

The authors declare that they have no competing interests.

\section{Consent for publication}

Written informed consent was obtained from the patient for publication of this case report and any accompanying images. A copy of the written consent is available for review by the Editor-in-Chief of this journal.

Ethics approval and consent to participate

Not applicable.

Received: 29 January 2016 Accepted: 6 October 2016

Published online: 01 November 2016

\section{References}

1. Ravina JH, Herbreteau D, Ciraru-Vigneron N, Bouret JM, Houdart E, Aymard A, Merland JJ. Arterial embolisation to treat uterine myomata. Lancet. 1995;346(8976):671-2.

2. Bradley LD. Uterine fibroid embolization: a viable alternative to hysterectomy. Am J Obstet Gynecol. 2009;201(2):127-35.

3. Dutton S, Hirst A, McPherson K, Nicholson T, Maresh M. A UK multicentre retrospective cohort study comparing hysterectomy and uterine artery embolisation for the treatment of symptomatic uterine fibroids (HOPEFUL study): main results on medium-term safety and efficacy. BJOG. 2007;114(11):1340-51.

4. Spies JB, Spector A, Roth AR, Baker CM, Mauro L, Murphy-Skrynarz K. Complications after uterine artery embolization for leiomyomas. Obstet Gynecol. 2002;100(5 Pt 1):873-80.
5. The Royal College of Obstetricians and Gynaecologists, Third edition. Clinical recommendations on the use of uterine artery embolisation (UAE) in the management of fibroids, Third edition. 2013.

6. Al-Fozan $\mathrm{H}$, Tulandi T. Factors affecting early surgical intervention after uterine artery embolization. Obstet Gynecol Surv. 2002;57(12):810-5.

7. Bérczi V, Valcseva É, Kozics D, Kalina I, Kaposi P, Sziller P, Várbíró S, Botos EM. Safety and Effectiveness of UFE in Fibroids Larger than $10 \mathrm{~cm}$. Cardiovasc Intervent Radiol. 2015;38(5):1152-6.

8. Choi HJ, Jeon GS, Kim MD, Lee JT, Yoon JH. Is uterine artery embolization for patients with large myomas safe and effective? A retrospective comparative study in 323 patients. J Vasc Interv Radiol. 2013;24(6):772-8.

9. Parthipun AA, Taylor J, Manyonda I, Belli AM. Does size really matter? Analysis of the effect of large fibroids and uterine volumes on complication rates of uterine artery embolisation. Cardiovasc Intervent Radiol. 2010;33(5):955-9.

10. Firouznia K, Ghanaati H, Sanaati M, Jalali AH, Shakiba M. Uterine artery embolization in 101 cases of uterine fibroids: do size, location, and number of fibroids affect therapeutic success and complications? Cardiovasc Intervent Radiol. 2008;31(3):521-6.

11. Volkers NA, Hehenkamp WJ, Birnie E, de Vries C, Holt C, Ankum WM, Reekers JA. Uterine artery embolization in the treatment of symptomatic uterine fibroid tumors (EMMY trial): periprocedural results and complications. J Vasc Interv Radiol. 2006;17(3):471-80.

12. Ustünsöz B, Uğurel MS, Bozlar U, Duru NK, Ustünsöz A. Is uterine artery embolization prior to myomectomy for giant fibroids helpful? Diagn Interv Radiol. 2007;13(4):210-2.

13. Butori N, Tixier H, Filipuzzi L, Mutamba W, Guiu B, Cercueil JP, Douvier S, Sagot $P$, Krausé $D$, Loffroy $R$. Interest of uterine artery embolization with gelatin sponge particles prior to myomectomy for large and/or multiple fibroids. Eur J Radiol. 2011;79(1):1-6.

14. Goldman KN, Hirshfeld-Cytron JE, Pavone ME, Thomas AP, Vogelzang RL, Milad MP. Uterine artery embolization immediately preceding laparoscopic myomectomy. Int J Gynaecol Obstet. 2012;116(2):105-8.

15. David M, Kröncke T. Preoperative Uterine Artery Embolisation for Large Uterine Fibroids with Subsequent Uterus Preservation - Three Case Histories and Review of the Literature. Geburtshilfe Frauenheilkd. 2012;72(6):539-42.
Submit your next manuscript to BioMed Central and we will help you at every step:

- We accept pre-submission inquiries

- Our selector tool helps you to find the most relevant journal

- We provide round the clock customer support

- Convenient online submission

- Thorough peer review

- Inclusion in PubMed and all major indexing services

- Maximum visibility for your research

Submit your manuscript at www.biomedcentral.com/submit
Ciomed Central 